\title{
Pediatric Hematology Providers' Contraceptive Practices for Female Adolescents and Young Adults with Sickle Cell Disease: A national survey
}

\author{
Megan Askew ${ }^{1}$, Arlene Smaldone ${ }^{2}$, Melanie Gold ${ }^{1}$, Kim Smith-Whitley ${ }^{3}$, John Strouse ${ }^{4}$, Jin \\ Zhezhen $^{5}$, and Nancy Green ${ }^{6}$ \\ ${ }^{1}$ New York-Presbyterian/Columbia University Medical Center \\ ${ }^{2}$ Columbia University Irving Medical Center \\ ${ }^{3}$ The Children's Hospital of Philadelphia \\ ${ }^{4}$ Duke University School of Medicine \\ ${ }^{5}$ Columbia University Mailman School of Public Health \\ ${ }^{6}$ Columbia University
}

February 27, 2022

\begin{abstract}
Background Adolescent and young adult (AYA) women with sickle cell disease (SCD) have increased pregnancy-related health risks and are prescribed potentially teratogenic medications, yet little is known about pediatric SCD provider contraceptive practices. We aimed to assess pediatric hematology providers' beliefs, practices, motivators, and barriers for providing contraceptive care to female AYA with SCD. Methods Guided by the Health Belief Model (HBM), we developed a 25-question, web-based survey to assess providers' practices. Survey links were distributed nation-wide to pediatric SCD and/or general hematology providers through their publicly available emails and by request to directors of U.S. accredited Pediatric Hematology-Oncology fellowship programs for distribution to their SCD providers. Data analysis included descriptive statistics, chi-square analysis, logistic regression. Results Of 177 respondents, 160 surveys meeting inclusion criteria were analyzed. Most providers reported counseling (77.5\%) and referring female AYA patients for contraception (90.8\%), but fewer reported prescribing contraception (41.8\%). Counseling practices significantly differed in trainees versus established providers $(54 \%$ vs. $85 \%, \mathrm{p}<0.001)$ with a similar trend for prescribing $(\mathrm{p}=0.05)$. Prescription practices did not differ significantly by provider beliefs regarding potential teratogenicity of hydroxyurea. Key motivators included patient request and disclosure of sexual activity. Key barriers included inadequate provider training, limited visit time, and perceived patient/parent interest. Conclusion Provider contraceptive practices for female AYA with SCD varied, especially by provider status. Health beliefs regarding teratogenic potential of hydroxyurea did not correlate with contraceptive practices. Clinical guidelines, provider training, and patient/parent decisionmaking tools may be tested to assess whether provider contraceptive practices could be improved.
\end{abstract}

\section{Hosted file}

Askew_SCDContraception_Manuscript_2.18.2022.docx available at https://authorea.com/users/ 462584/articles/557983-pediatric-hematology-providers-contraceptive-practices-forfemale-adolescents-and-young-adults-with-sickle-cell-disease-a-national-survey

\section{Hosted file}

Table1_SCDContraceptionManuscript 2.18.2022.docx available at https://authorea.com/users/ 462584/articles/557983-pediatric-hematology-providers-contraceptive-practices-forfemale-adolescents-and-young-adults-with-sickle-cell-disease-a-national-survey 


\section{Hosted file}

Table2_SCDContraceptionManuscript 2.18.2022.docx available at https://authorea.com/users/ 462584/articles/557983-pediatric-hematology-providers-contraceptive-practices-forfemale-adolescents-and-young-adults-with-sickle-cell-disease-a-national-survey

\section{Hosted file}

Table 3_SCDContraceptionManuscript 2.18.2022.docx available at https://authorea.com/users/ 462584/articles/557983-pediatric-hematology-providers-contraceptive-practices-forfemale-adolescents-and-young-adults-with-sickle-cell-disease-a-national-survey

\section{Hosted file}

Table 4_SCDContraceptionManuscript 2.18.2022.docx available at https://authorea.com/users/ 462584/articles/557983-pediatric-hematology-providers-contraceptive-practices-forfemale-adolescents-and-young-adults-with-sickle-cell-disease-a-national-survey

\section{Hosted file}

Table5_SCDContraceptionManuscript 2.18.2022.docx available at https://authorea.com/users/ 462584/articles/557983-pediatric-hematology-providers-contraceptive-practices-forfemale-adolescents-and-young-adults-with-sickle-cell-disease-a-national-survey 


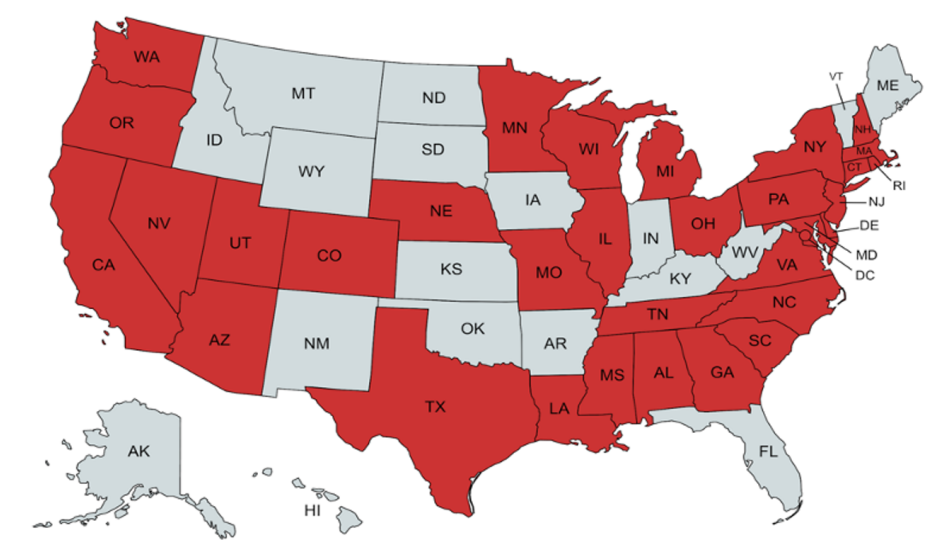

FIGURE 1 Geographic Distribution of Survey Respondents (in red), by U.S. state.

Respondents identified their primary work site in a total of 32 states of the District of Columbia. 